\title{
Proteolytic Enzymes from Extremely Halophilic Bacteria
}

\author{
By P. NORBERG AND B. v. HOFSTEN \\ Institute of Biochemistry, University of Uppsala, Uppsala, Sweden
}

(Accepted for publication I October 1968)

\begin{abstract}
SUMMARY
Halobacterium strains produce a truly extracellular proteinase which degrades gelatine and casein. It has a pH optimum of about 8 and depends upon divalent cations and a high concentration of $\mathrm{NaCl}$ or $\mathrm{KCl}$ for activity and stability. Proteolytic enzymes were also found in cell homogenates obtained by ultra sonic treatment. A caseinolytic enzyme, probably different from the extracellular one, is associated with particles which sediment upon ultracentrifugation. A soluble peptidase of lower molecular weight is also present in the extract. Both enzymes are dependent upon divalent cations and a high concentration of $\mathrm{NaCl}$ or $\mathrm{KCl}$ for activity. In contrast to other halophilic enzymes, the proteolytic enzymes of Halobacterium salinarium are more active in the presence of $\mathrm{NaCl}$ than $\mathrm{KCl}$ at equimolar concentrations.
\end{abstract}

\section{INTRODUCTION}

Bacteria of the genus Halobacterium are widely distributed in brines of high salt concentration. They are thus conspicuous in solar evaporation ponds of salt works, where they often become the dominating type of organisms when the salt concentration rises above $25 \%$. The extremely halophilic bacteria are best cultivated in complex media containing peptones and yeast extract to which at least $15 \%(\mathrm{w} / \mathrm{v}) \mathrm{NaCl}$ has been added. Best growth is obtained in media containing about $25 \%$ salt, and when bacteria are transferred to solutions with a salt concentration of less than about Io $\%$ they lyse rapidly.

The unusual properties of halophilic bacteria make them interesting objects of study for both microbiologists and biochemists, and Larsen (1967) summarized the result of a large number of investigations on them. Special methods are often necessary in studies of their metabolism and conventional procedures are unsuitable for the purification and assay of 'halophilic' enzymes.

The extreme halophiles do not generally grow well on carbohydrates but they have a well-developed enzyme apparatus for metabolizing amino acids. In order to utilize the proteins of dead organisms in salt brines the bacteria must form proteolytic enzymes. Gibbons (1957) found that 45 out of 49 tested strains were gelatinolytic, and most of these strains also degraded casein. However, a closer study of the properties of the proteolytic enzymes of such strains has apparently not been made. It is known that the bacteria have an intracellular concentration of $\mathrm{NaCl}+\mathrm{KCl}$, which is approximately the same as the $\mathrm{NaCl}$ concentration of the growth medium. The halophilic bacteria's enzymes are thus active at salt concentrations which inhibit or even denature many enzymes of non-halophilic organisms. This must be reflected in marked differences in the composition and properties of the protein molecules. Ingram (1947) has 
suggested that the halophilic enzymes are smaller than most other enzymes, which would make them more resistant to being salted out. However, no halophilic enzymes have yet been studied in sufficient detail to give substantial support to this hypothesis.

\section{METHODS}

Bacterial strains. Most experiments were made with a number of Halobacterium strains obtained from Professor Helge Larsen, Trondheim. Some comparative studies were also made with halophilic bacteria isolated directly from Mediterranean Sea salt or salted fish at this laboratory.

Growth conditions. The bacteria were grown in medium 73, which was developed in this laboratory: $\mathrm{MgSO}_{4} \cdot 7 \mathrm{H}_{2} \mathrm{O}, \mathrm{ro}$; $\mathrm{KCl}, 5 \mathrm{~g} ; \mathrm{CaCl}_{2} \cdot \mathrm{H}_{2} \mathrm{O}, 0.2 \mathrm{~g}$; Mediterranean Sea salt (mainly $\mathrm{NaCl}$ ), $250 \mathrm{~g}$; gelatine (Oxoid), $\mathrm{I0} \mathrm{g}$; yeast extract (Difco), I g; distilled water to I 1.; $\mathrm{pH} 7$. Some commercial preparations of gelatine were unsuitable because of low solubility in the salt solution. This medium gave good growth and better production of proteolytic enzymes than other media described. The bacteria were grown in Erlenmeyer or Fernbach flasks incubated at $37^{\circ}$ on a rotary shaker at I 80 oscillations/min. When the bacteria were grown on solid media, $\mathrm{I} \cdot 5 \%(\mathrm{w} / \mathrm{v})$ agar was added.

Measurements of growth. Cell densities of samples from liquid cultures were measured in tubes of $16 \mathrm{~mm}$ diameter in a Beckman Colorimeter Model $\mathrm{C}$, using a red filter.

Determination of enzyme activities. Hydrolysis of casein was measured by incubating I ml. of enzyme solution (usually containing $25 \%$ (w/v) $\mathrm{NaCl}$ ) with I $\mathrm{ml}$. of a I \% (w/v) solution of casein (Merck) in $0.1 \mathrm{M}$-tris which was adjusted to $\mathrm{pH} 8$ with $\mathrm{HCl}$ and contained $15 \%(\mathrm{w} / \mathrm{v}) \mathrm{NaCl}$. The reaction was carried out at $37^{\circ}$ and terminated, usually after $60 \mathrm{~min}$, by the addition of $3 \mathrm{ml}$. of $5 \%(\mathrm{w} / \mathrm{v})$ trichloroacetic acid (TCA). After filtration, the extinction of the filtrate was read at $280 \mathrm{~m} \mu$ against a reaction blank for each sample.

The hydrolysis of peptides was determined at $37^{\circ}$ by the ninhydrin procedure of Matheson \& Tattrie (1964) with 0.1 \% L-leucyl-glycine as substrate, in the presence of $25 \%(\mathrm{w} / \mathrm{v}) \mathrm{NaCl}$; incubation time $60 \mathrm{~min}$.

\section{RESULTS}

Studies of enzyme formation. The amount of TCA-precipitable gelatine was decreased roughly in proportion to the rate of growth when Halobacterium salinarium I was cultivated in medium 73. Figure I shows that there was very little protein left in the medium by the time the culture reached the stationary phase of growth.

Proteolysis was also demonstrated by growing the bacteria on the same medium solidified with agar. The agar plates were inoculated in the middle with a loop so that one colony was obtained. The enzyme activity was then determined by measuring the clear zones around the colonies. Marked differences in proteolytic activities of different strains were observed by this method. The highest activity was obtained with a colourless mutant strain, Halobacterium salinarium I M, and a vacuolated strain designated $H$. salinarium 5 . Relatively small zones were obtained with the wild-type strain $H$. salinarium I and almost no activity could be detected after growth of 
H. cutirubrum, strain CCNRLO 9. A number of coccoid halophilic bacteria of the Sarcina type and several strains freshly isolated from sea salt and salted fish were found not to be proteolytic with this method.

The formation of extracellular proteinase in liquid cultures was studied quantitatively by removing samples and determining their activity against casein. Figure I shows the progress of growth and enzyme formation by strain $H$. salinarium $\mathrm{I} M$ in medium 73 . Merthiolate $(0.01 \% \mathrm{w} / \mathrm{v})$ was without effect on the proteolytic activity and was therefore added to the samples to stop growth. There were only small differences in caseinolytic activity between samples which had been centrifuged free from bacteria and of samples taken directly from the culture. Furthermore, dense suspensions of growing bacteria which had been washed and suspended in a salt solution of similar

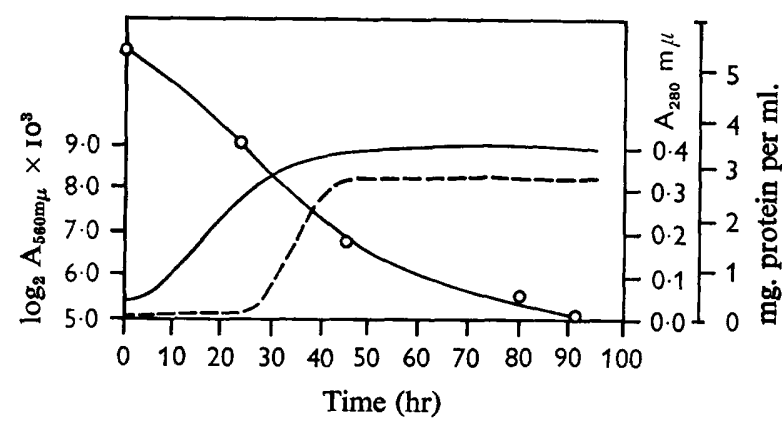

Fig. I

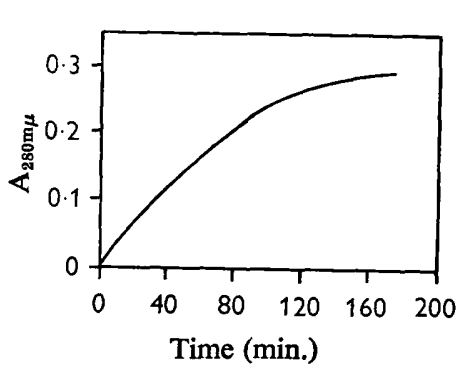

Fig. 2

Fig. I. Gelatinolytic and caseinolytic ativity of $H$. salinarum I cultivated in medium 73 . $\longrightarrow$, Growth of the bacteria $\left(\mathrm{A}_{280 \mathrm{~m}_{\mu}}\right) ; \mathrm{O}-\mathrm{O}$, the amount of TCA-precipitable gelatine in the cell-free medium as determined gravimetrically $(\mathrm{mg}$. protein $/ \mathrm{ml}$.); - - - , the caseinolytic activity of the medium $\left(\log _{2} \mathrm{~A}_{560 \mathrm{~m} \mu} \times 10^{3}\right)$.

Fig. 2. Hydrolysis of casein by cell-free medium after growth of $H$. salinarium I $\mathbf{M}$.

composition as medium 73 were without detectable activity. Hence the enzyme was truly extracellular and there was very little caseinolytic enzyme associated with the surface of the cells. As will be shown later, a measurable caseinolytic activity was associated with particles obtained by ultrasonic treatment, but this has different properties from the extracellular proteinase. Furthermore, the cell-bound proteinase had such a low activity against casein under the conditions of our assay that no measurable increase in activity was detected when culture samples were treated ultrasonically before assay.

Figure 2 shows that cell-free culture samples degraded casein to a rather limited degree. The $\mathrm{pH}$ optimum for the reaction was about 8 in $0.05 \mathrm{mM}$-phosphate buffer containing $20 \%(\mathrm{w} / \mathrm{v}) \mathrm{NaCl}$. There was only slight activity at $\mathrm{pH} 6 \cdot 5$.

It was necessary to concentrate cell-free culture samples several times by ultrafiltration before gel filtration experiments could be made. When such enzyme solutions were filtered through a column with Sephadex G-10o equilibrated with $0 . \mathrm{I} \mathrm{M}$-tris- $\mathrm{HCl}, \mathrm{pH} 8.0$, and containing the salts of medium 73 , all the proteolytic activity was obtained in a single peak about 0.5 void volumes after the initial unretarded high molecular weight material.

Cell-bound proteolytic activities. Halobacteria were washed twice in a solution 
of $(25 \% \mathrm{w} / \mathrm{v}) \mathrm{NaCl}$ and $0 . \mathrm{I} \%(\mathrm{w} / \mathrm{v}) \mathrm{CaCl}_{2}$, suspended as a dense suspension in the same solution, and completely disintegrated by treatment in a Raytheon $250 \mathrm{~W}$, Io kc., sonic oscillator for $30 \mathrm{~min}$. A low but measurable caseinolytic activity was found in such homogenates, but about $90 \%$ of this activity was associated with particles (cell envelope particles?) which sedimented during centrifugation at $105,000 \mathrm{~g}$ for I hr. Attempts to dissociate the enzyme from these particles by treatment with various detergents have so far been unsuccessful. The $\mathrm{pH}$ optimum for hydrolysis of

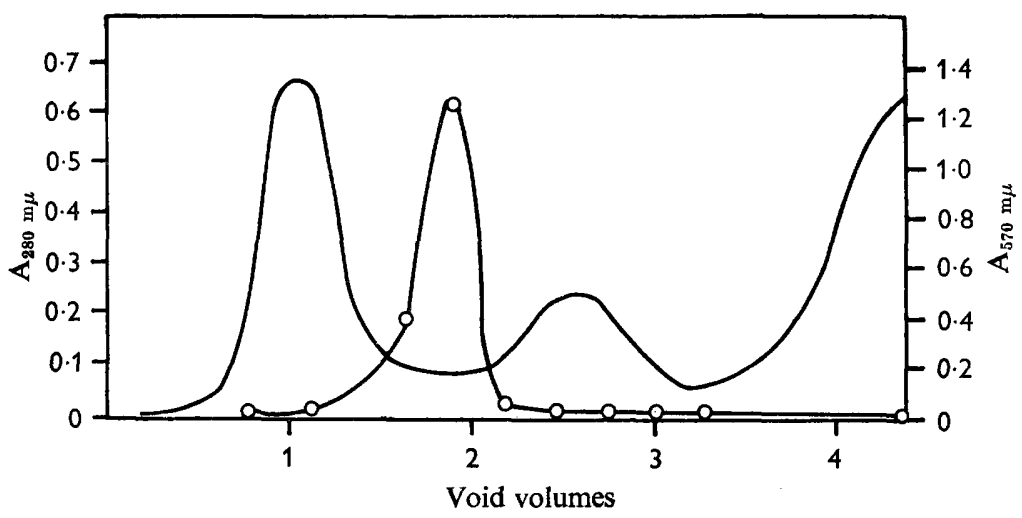

Fig. 3. Gel filtration of cell extract of $\boldsymbol{H}$. salinarium I on Sephadex G-IOO in the presence of of $25 \% \mathrm{NaCl}$. - Material distribution. $\mathrm{O}-\mathrm{O}$, Peptidase activity measured against L-leucylglycine.

casein by cell homogenates was significantly lower, about 7 , than the value obtained for the extracellular enzyme. Furthermore, the cell-bound proteinase was completely inhibited by addition of $0.04 \mathrm{mg}$. poly-L-proline per ml., a compound which inhibits some proteolytic enzymes, (Sela \& Katchalski 1959). No such inhibition was observed with the extracellular enzyme, and none of the enzymes were inhibited by soybean trypsin inhibitor or chicken egg-white trypsin inhibitor when 0.0r $\mathrm{mg}$. of these were added per ml.

The halophilic bacteria also contained a peptidase which cleaved L-leucylglycine. This enzyme was not particle-bound and the gel filtration diagram shown in Fig. 3 indicates that it had a lower molecular weight than other soluble enzymes in cell extracts.

Influence of $\mathrm{NaCl}, \mathrm{KCl}$ and divalent ions on the enzymes. Dialysis overnight at $+4^{\circ}$ of cell-free culture samples or cell homogenates against solutions of $25 \%(w / v) ~ N a C l$ did not lower the enzyme activities. However, dialysis against a neutral $\mathrm{NaCl}$ solution containing $0.01 \mathrm{M}$-EDTA caused complete inactivation of both the extracellular and the cell-bound proteinase and the peptidase. Attempts to obtain reactivation by dialysis against solutions containing $25 \%(\mathrm{w} / \mathrm{v}) \mathrm{NaCl}$ and either $0.02 \mathrm{M}^{-} \mathrm{MgSO}_{4}$, $\mathrm{ZnSO}_{4}$ or $\mathrm{MnSO}_{4}$ were unsuccessful with the extracellular proteinase and the peptidase: $70-90 \%$ of the original activity of the particle-bound proteinase could be reactivated by $\mathrm{Zn}^{2+}$ or $\mathrm{Mn}^{2+}$ but not by $\mathrm{Mg}^{2+}$. These results indicate that the enzymes are dependent on divalent metal ions for stability and/or activity but the ions are rather firmly bound to the enzyme proteins.

All enzymes of the halophilic bacteria appear to be rapidly and irreversibly denatured in ordinary buffers which do not contain large concentrations of $\mathrm{NaCl}$ or 
$\mathrm{KCl}$, (Larsen, 1967). The proteolytic enzymes are no exceptions to this rule and we have not been able to reactivate them by dialysis against solutions containing the salts of medium 73. The influence of varied salt concentrations on the assay was also tested. Cell-free culture samples and cell homogenates were dialysed against solutions containing different concentrations of $\mathrm{NaCl}$ or $\mathrm{KCl}$, then assayed at concentrations similar to those of the dialysis solutions. As shown in Fig. 4 the caseinolytic and the peptidase activities were constantly higher in the presence of $\mathrm{NaCl}$ than ${ }_{-} \mathrm{KCl}$.

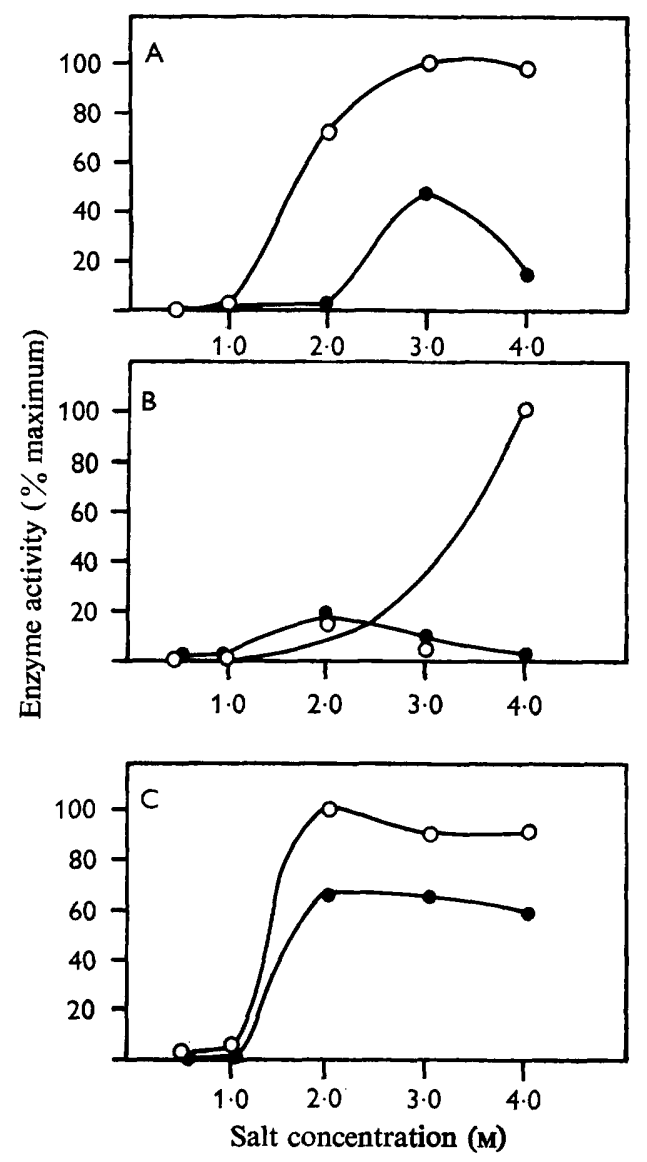

Fig. 4. Effects of $\mathrm{NaCl}$ and $\mathrm{KCl}$ on the enzyme activities. To facilitate comparisons the highest activity value for each enzyme has been designated arbitrarily as $100 \%$ in each experiment. A, Extracellular caseinolytic activity. B, Cell-bound caseinolytic activity. $\mathrm{C}$, Cell-bound peptidase activiy. $\mathrm{O}-\mathrm{O}, \mathrm{NaCl} ; 0, \mathrm{KCl}$.

\section{DISCUSSION}

One would expect the extremely halophilic bacteria to be proteolytic because they occur in protein-rich salt brines and they cause salted fish to spoil. Our results show that some Halobacterium strains do form a true extracellular proteinase, but that different strains vary in proteolytic activity. The low activity of Halobacterium salinarium I and $N$. cutirubrum may depend on the long time during which these strains 
have been kept in culture collections, because proteolysis was a distinguishing characteristic of $H$. cutirubrum when it was originally isolated by Lochhead (1934) and Anderson (1954).

Christian (1956) and Brown \& Gibbons (I955) have concluded that potassium ions play an important role in the metabolism of halophilic bacteria by activating certain enzymes. Several enzymes are more active in the presence of $\mathrm{KCl}$ than $\mathrm{NaCl}$ (Baxter \& Gibbons, 1956; Baxter, 1959). An exception is the cytochrome oxidase of $H$. salinarium, which is activated equally well by either $\mathrm{KCl}$ or $\mathrm{NaCl}$. The proteolytic enzymes studied by us have a higher activity with $\mathrm{NaCl}$ than with $\mathrm{KCl}$. In the case of the extracellular proteinase this is not surprising in view of its occurrence in environments where $\mathrm{NaCl}$ dominates.

More experimental work is needed before anything can be said about the physiological function and properties of the cell-bound proteolytic enzymes. It is not impossible that the particle-associated proteinase might be a precursor of the extracellular enzyme, but it may also play a role in intracellular protein turnover.

Our finding that the proteolytic enzymes of the extreme halophiles are irreversibly denatured in ordinary buffers make their purification and characterization difficult. Holmes \& Halvorsen (1965) have recently managed to purify a couple of halophilic enzymes in the absence of high salt concentrations during the fractionation, but only a small fraction of the original enzyme activities was recovered in the pure enzyme proteins. Recent developments in separation techniques offer some promise in solving the special problems of the purification of halophilic enzymes, but they still present an interesting challenge to the biochemist.

We are much indebted to Professor Helge Larsen for introducing us into the biology of the extremely halophilic bacteria and for helpful discussions and suggestions. This work has been supported by grants from Magnus Bergwalls Stiftelse, Stockholm.

\section{REFERENCES}

ANDERSON, H. (1954). The reddening of salted hides and fish. Appl. Microbiol. 2, 64 .

BAXTER, R. M. (1959). An interpretation of the effects of salts on the lactic dehydrogenase of Halobacterium salinarium. Can. J. Microbiol. 5, 47.

BAXTER, R. M. \& GibBons, N. E. (1956). Effects of sodium and potassium chloride on certain enzymes of Micrococcus halodenitrificans and Pseudomonas salinaria. Can. J. Microbiol. I, 486.

Brown, H. J. \& GibBons, N. E. (1955). The effect of magnesium potassium and iron on the growth and morphology of red halophilic bacteria. Can. J. Microbiol. x, 486.

Christian, J. H. B. (1956). The physiological basis of salt tolerance in halophilic bacteria. Doctoral thesis, University of Cambridge.

Gibbons, N. E. (1957). The effect of salt concentration on the biochemical reactions of some halophilic bacteria. Can. J. Microbiol. 3, 249.

Holmes, P. K. \& Halvorsen, H. O. (1965). Purification of a salt requiring enzyme of Halobacterium salinarium. J. Bact. 90, 316.

INGRAM, M. (1947). A theory relating the action of salts on bacterial respiration to their influence on the solubility of proteins. Proc. R. Soc. B I34, I8I.

LARSEN, H. (1967). Biochemical aspects of extreme halophilism. In Advances in Microbiol Physiology. Ed. by Rose A. H. and J., F. Silkinson, Vol. I, p. 97. London and New York: Academic Press.

LochHEAD, A. G. (1934). Bacteriological studies on the red discoloration of salted hides. Can. J. Res. 10, 275.

Matheson, A. T. \& TATtrie, B. L. (1964). A modified Yemm and Cocking ninhydrin reagent for peptidase assay. Can. J. Biochem. 42, 95.

Sela, M. \& Katchalski, E. (1959). Biological properties of polyamino acids. Adv. Protein Chem. I4, 392 . 